\title{
PERUBAHAN MIKROBIOLOGI SELAMA PEMBUSUKAN IKAN TEMBANG (Sardinella fimbriata) YANG DIES DAN DISIMPAN PADA SUHU KAMAR
}

\author{
Ninock Indriati") dan Endang Sri Heruwati*)
}

\begin{abstract}
ABSTRAT
Ikan tembang seringkali mendapatkan penanganan yang kurang layak dalam arti tidak didinginkan dengan cukup karena nilai jual yang relatif rendah, sedangkan biaya pendinginan relatif tinggi. Di Indonesia, cara pendinginan yang dianggap mudah dan praktis adalah dengan pengesan, namun demikian daya awet dalam es, selain tergantung pada jenis ikan, juga dipengaruhi oleh suhu dan tipe lingkungan dimana ikan ditangkap. Perubahan yang sangat dominan dalam proses pembusukan ikan disebabkan aktivitas mikrobial. Untuk itu diperlukan penelitian untuk mempelajari perubahan mikrobiologis selama pembusukan ikan tembang yang disimpan dalam es, dibandingkan dengan bila dibiarkan pada suhu kamar.
\end{abstract}

Hasil penelitian menunjukkan bahwa flora bakteri yang mendominasi ikan tembang segar adalah Aeromonas, Enterobacter, Corynebacter, dan kelompok Moraxella-Acinetobacter, tetapi pada saat membusuk, ikan yang disimpan dalam es didominasi oleh kelompok Moraxella-Acinetobacter dan Flavobacterium, sedangkan ikan yang disimpan pada suhu kamar didominasi oleh Enterobacter dan Aeromonas. Perubahan komposisi bakteri ini juga berpengaruh terhadap pola pembusukan. Saat ditolak oleh panelis, ikan yang disimpan dalam es tidak berbau sebusuk ikan yang disimpan pada suhu kamar, karena Moraxella-Acinetobacter dan Flavobacterium tidak menghasilkan $\mathrm{H}_{2} \mathrm{~S}$, indol, dan acetoin seperti halnya Enterobacter dan Aeromonas.

Dari pengamatan organoleptik terlihat bahwa ikan tembang yang disimpan dalam es mempunyai daya awet 13 hari, sedangkan pada suhu kamar daya awetnya hanya 12 jam saja.

Jumlah basa menguap (TVB), trimetilamin (TMA), dan amonia, yang dianggap sebagai indikator pembusukan ikan, baik pada penyimpanan dalam es maupun suhu kamar menunjukkan peningkatan selama penyimpanan walaupun dengan laju dan nilai yang berbeda untuk kedua perlakuan.

\section{ABSTRACT: Microbial Changes Aseocinted with Spoilage of Fringescale Sardine (Serdimelle fimbriata) During Storage in lce and at Ambient Tempera- tures, by: Nimoek Indriati and Endang Sri Henowati.}

Fringescale sardine often handled and cooled improperly due to its low economic value. In Indonesia the simplest and most practical way to chill fish is by icing, however, the effectivity of fish preservation using ice does not only depends on the species of fish, but also on the temperature and types of environment where the fish are caught. The significant changes occurred during spoilage of fish is mainly due to microbial activity. Therefore, study on microbial changes during spoilage of iced fringescale sardine is needed to compare with those stored at ambient temperature.

Peneliti pada Instal asi Penelitian Perikanan Laut Slipi, Jakarta 
Indriati, N. dan Heruwati, E.S.

Result of the experiments revealed that the bacterial flora of freshly caught fringescale sardine were Aeromonas, Enterobacter, Corynebacter, and Moraxella-Acinetobacter group, while at the time of rejection, fish kept in ice were predominated by Moraxella-Acinetobacter group and Flavobacterium, and those stored at ambient temperature, the native flora were predominated by Enterobacter and Aeromonas. Changes of the composition of bacterial flora seems to give effect on the spoilage pattern. At the time of rejection, the ice-stored fish did not produce strong putrid odour as undergone by fish kept at ambient temperature. This happened because the bacteria responsible for spoilage in ice-stored fish, Moraxella-Acinetobacter and Flavobacterium do not produce $\mathrm{H}_{2} \mathrm{~S}$, indol, nor acetoin, as Enterobacter and Aeromonas do.

From organoleptic assessment, it was shown that fish which were kept in ice had storage life of 13 days whereas fish which were stored at ambient temperature had spoiled in 12 hours.

Chemical compound used as spoilage indicators, that are total volatile bases (TVB), trimethylamine (TMA), and ammonia increased during storage for both treatments but at different rates and values.

KEYWORDS: Cbilling, microbial cbanges, spoilage, fringscale sardine

\section{PENDAHULUAN}

Ikan tembang (Sardinella fimbriata) adalah salah satu jenis ikan pelagis kecil yang potensinya cukup besar di Indonesia. Dari total produksi 1993 sebesar 152.500 ton, kontribusi terbesar (34\%) adalah perairan utara Jawa diikuti oleh perairan sekitar Sulawesi (25\%). Dibandingkan dengan ikan lain seperi udang, tuna, cumi-cumi dan sebagainya, ikan tembang nilai ekonomisnya relatif rendah sehingga tidak banyak mendapatkan perhatian dalam penanganan dan pengembangannya. Namun demikian sebenarnya justru karena harganya yang murah, ikan ini diharapkan dapat menjadi tumpuan penyediaan sumber protein hewani bagi masyarakat golongan menengah ke bawah. Untuk itu, faktor mutu tidak dapat diabaikan, karena menyangkut kesehatan dan keselamatan masyarakat banyak.

Dalam praktek sehari-hari, es banyak digunakan sebagai bahan pengawet ikan karena lebih sederhana penggunaannya tanpa memerlukan sumber energi listrik. Namun demikian kemampuan es mengawet ikan sangat tergantung pada suhu dan tipe lingkungan di mana ikan ditangkap. Shewan (1977) menyatakan bahwa spesies ikan dari daerah tropika mempunyai masa simpan dalam es yang lebih panjang dibandingkan dengan yang berasal dari daerah subtropika karena flora alami yang terdapat dalam ikan daerah tropika sebagian besar adalah organisme mesofil, yang mempunyai persyaratan pertumbuhan optimal pada suhu $20-45^{\circ} \mathrm{C}$, sehingga sulit tumbuh dalam es. Adapun bakteri alami ikan subtropika umumnya bersifat psikrofil, yang lebih menyukai suhu rendah (hingga $0^{\circ} \mathrm{C}$ ), sehingga bila disimpan dalam es, pertumbuhan terus berlangsung dan mengakibatkan pembusukan. Akan tetapi 
untuk ikan penghasil hipoksantin, walaupun berasal dari daerah tropika, masa simpannya dalam es tidak lebih panjang dari ikan yang berasal dari subtropika karena hipoksantin, yang pembentukannya sangat cepat, menjadi faktor pembatas kesegaran ikan, artinya, walaupun belum busuk dalam hal bau dan rasanya, namun sudah ditolak karena dianggap tidak segar (Bremner et al., 1988).

Penelitian mengenai pola pembusukan ikan yang disimpan dalam es telah banyak dilakukan, misalnya untuk ikan kakap/Lutjanus sanguineus, madidihang (yellowfin tuna), tuna kecil dan cakalang (Tambunan dan Saifurijal, 1972), kembung atau banyar/Rastrelliger kanagurta (Bustaman et al., 1982), beronang/ Siganus sp. (Putro et al., 1984), belanak/Mugil sp. (Saleh et al., 1984a), dan cakalang/Katsuwonus pelamis (Saleh et al., 1984b). Namun demikian penelitian tersebut hanya sedikit sekali menguraikan masalah pola pembusukan secara bakterial, yang sebenarnya justru merupakan pemegang peranan utama dalam proses pembusukan ikan.

Penelitian serupa untuk ikan kerapu lumpur (Epinepbelus tauvina) dilakukan oleh Anggawati et al. (1990). Penelitian ini membahas dengan lebih mendalam mengenai pola pembusukan ikan dikaitkan dengan komposisi bakteri pada ikan yang dies dengan cara yang benar, atau dies tidak sempurna, seperti praktek yang sekarang ini dilakukan nelayan, dibandingkan dengan yang sama sekali tidak menggunakan es. Dari penelitian ini jelas terlihat bahwa pola pembusukan sangat tergantung pada komposisi bakteri yang berperan dalam pembusukan, sedangkan jenis bakteri yang mendominasi sangat dipengaruhi oleh suhu penyimpanan. Dengan demikian akan dapat diketahui bagaimana cara menyimpan ikan yang terbaik sehingga proses pembusukan dapat dihambat secara maksimal.

Hasil-hasil penelitian di atas tidak sepenuhnya dapat diterapkan untuk semua jenis ikan karena diketahui bahwa pola pembusukan sangat dipengaruhi oleh beberapa faktor, antara lain jenis dan ukuran ikan, komposisi kimia yang spesifik dari setiap jenis misalnya kadar lemak, kadar dan jenis asam amino, kadar glikogen, dan zat-zat lain. Oleh sebab itu diperlukan penelitian lanjutan untuk melihat pola pembusukan dari berbagai jenis ikan yang lebih spesifik. Dalam penelitian ini diamati perubahan mutu mikrobiologis organoleptik, dan khemis ikan tembang (Sardinella fimbriata) yang dies, dibandingkan bila disimpan pada suhu kamar.

\section{BAHAN DAN METODE}

Ikan tembang yang digunakan dalam penelitian ini ditangkap pada pagi hari di perairan sekitar Pulau Lancang, di utara Jakarta, dengan menggunakan jaring tembang. Setelah jumlah ikan mencukupi kebutuhan untuk penelitian, 
Indriati, N. dan Heruwati, E.S.

kapal segera kembali ke TPI Muara Angke, Jakarta, dengan menempuh perjalanan 3 jam. Kisaran panjang total ikan adalah $8,7-10,5 \mathrm{~cm}$ dengan bobot antara 8,0-8,3 gram/ekor. Pengesan dilakukan di tengah laut segera setelah ikan ditangkap dengan cara memasukkan ke dalam peti berinsulasi bersama es hancuran sejumlah sama dengan bobot ikan. Penyusunan ikan dalam es hancuran dilakukan secara berlapis-lapis mengikuti petunjuk cara pengesan yang memenuhi persyaratan (Wheaton dan Lawson, 1985). Untuk perlakuan suhu kamar, ikan dimasukkan ke dalam palka mengikuti praktek yang selama ini dilakukan oleh nelayan.

Setelah kapal mendarat, ikan dibawa ke laboratorium Balai Penelitian Perikanan Laut Slipi, Jakarta yang berjarak tempuh kurang lebih satu jam.

Di laboratorium, ikan yang akan disimpan pada suhu kamar diletakkan di atas nampan yang di bawahnya dikelilingi dengan lap basah. Ini dimaksudkan untuk menjaga kelembaban agar tetap stabil, yaitu antara $63-75 \%$. Pengamatan mikrobiologi, kimiawi, dan organoleptik dilakukan setiap 3 jam hingga ikan dinyatakan busuk. Untuk ikan yang dies, peti pendingin diletakkan sedemikian rupa sehingga air yang berasal dari es yang meleleh dapat mengalir ke luar. Guna menggantikan es yang mencair, setiap 2 hari sekali ditambahkan hancuran es. Pengamatan mikrobiologi, kimiawi, dan organoleptik dilakukan setiap 2 hari.

Pengamatan mikrobiologi dilakukan menggunakan parameter jumlah total bakteri, jumlah bakteri enterik, dan jumlah bakteri penghasil asam sulfida $\left(\mathrm{H}_{2} \mathrm{~S}\right)$. Untuk menentukan jumlah bakteri total digunakan nutrient agar (NA) sebagai media pertumbuhan, sedangkan untuk bakteri enterik dan penghasil $\mathrm{H}_{2} \mathrm{~S}$ berturut-turut adalah violet red bile glucose agar (VRBGA) dan iron agar (IA). Juga dilakukan pengamatan terhadap komposisi jenis bakteri pada awal dan akhir penyimpanan dari kedua perlakuan suhu.

Untuk uji kimiawi, selain pengamatan kadar abu (dengan pengabuan tanur), protein (metode Kyeldabl), lemak (metode soxblet), garam (metode Volbard) dan kadar air (metode pengeringan dalam oven) secara proksimat, juga diamati perubahan $\mathrm{pH}$ (menggunakan $\mathrm{pH}$-meter), kadar amonia (metode titrasi), total basa menguap (TVB) dan kadar trimetilamin (TMA), keduanya menggunakan metode Conway.

Pengamatan organoleptik dilakukan terhadap rasa, rupa, bau, dan tekstur oleh 8 orang panelis yang berpengalaman. Untuk ikan mentah, penilaian dilakukan terhadap ikan yang masih utuh, tidak disiangi dan tidak dicuci. Untuk ikan yang dinilai dalam keadaan masak (cooked condition), pemasakan dilakukan dengan mengukus contoh ikan yang telah dibungkus dengan lempeng tipis alumunium (alumunium foil) selama 10-15 menit, penilaian dilakukan dengan menggunakan sistem nilai demerit (Branch dan Vail, 1985). 
Nilai demerit pada ikan mentah dimulai dari 0 (untuk ikan segar) sampai 39 (untuk ikan busuk), sedangkan untuk ikan masak, nilai demerit dimulai dari 5 (untuk ikan segar) sampai 1 (untuk ikan busuk).

\section{HASIL DAN PEMBAHASAN}

\section{Karakterisasi Itan Percobaan}

Sebelum dilakukan percobaan dilakukan karakterisasi ikan untuk mengetahui dengan tepat kondisi kimiawi dan mikrobiologi ikan yang digunakan. Karakterisasi pada akhir percobaan dilakukan pula untuk mengetahui perubahan yang terjadi selama penyimpanan. Hasil karakterisasi dapat dilihat pada Table 1 .

Table 1. Chemical and microbiological conditions of fringescale sardine at the initial and end of storage periods (wet basis)

\begin{tabular}{lcccc}
\hline \multirow{2}{*}{ Parameter } & \multicolumn{2}{c}{ Ambient temp.storage } & \multicolumn{2}{c}{ Iced storage } \\
\cline { 2 - 5 } & bour - 0 & bour - 12 & day - 0 & day - 13 \\
\hline Fat, \% & 0.51 & 0.60 & 0.37 & 0.32 \\
Moisture, \% & 73.90 & 68.26 & 73.08 & 77.34 \\
Ammonia, \% & 0.19 & 0.44 & 0.14 & 0.46 \\
TVB, mgN\% & 22.3 & 35.7 & 17.6 & 22.9 \\
TMA, mgN\% & 2.4 & 19.8 & 1.9 & 7.1 \\
pH & 6.78 & 6.38 & 6.81 & 6.92 \\
APC,col/g & $1.56 \times 10^{6}$ & $1.87 \times 10^{9}$ & $1.67 \times 10^{5}$ & $2.80 \times 10^{6}$ \\
Enterics,col/g & $1.03 \times 10^{6}$ & $2.96 \times 10^{8}$ & $2.96 \times 10^{4}$ & $6.20 \times 10^{5}$ \\
$H_{2}$ S producers, col/g & $2.60 \times 10^{5}$ & $4.70 \times 10^{8}$ & $2.43 \times 10^{4}$ & $9.67 \times 10^{5}$ \\
\hline
\end{tabular}

\section{Suhu Penyimpanan}

Selama penelitian suhu ruangan adalah $30^{\circ} \mathrm{C}$ dengan kelembaban $72 \%$ dan suhu ikan yang disimpan adalah $25^{\circ} \mathrm{C}$. Menjelang tengah malam suhu ruangan mengalami penurunan, dengan suhu terendah tercatat $28,5^{\circ} \mathrm{C}$ dengan ke- 
Indriati, N. dan Heruwati, E.S.

lembaban $74 \%$ dan suhu ikan naik menjadi $26^{\circ} \mathrm{C}$. Adapun ikan yang disimpan dalam hancuran es menunjukkan suhu $0-6^{\circ} \mathrm{C}$ pada pusat daging dengan suhu sekeliling sekitar $\mathrm{O} \pm 0,3^{\circ} \mathrm{C}$.

\section{Pengamatan Mikrobiologi}

Hasil pengamatan mikrobiologi menunjukkan bahwa jumlah bakteri total, bakteri enterik, dan penghasil $\mathrm{H}_{2} \mathrm{~S}$, yang merupakan bakteri indikator pembusukan, terus meningkat selama penyimpanan pada suhu kamar (Figure 1).

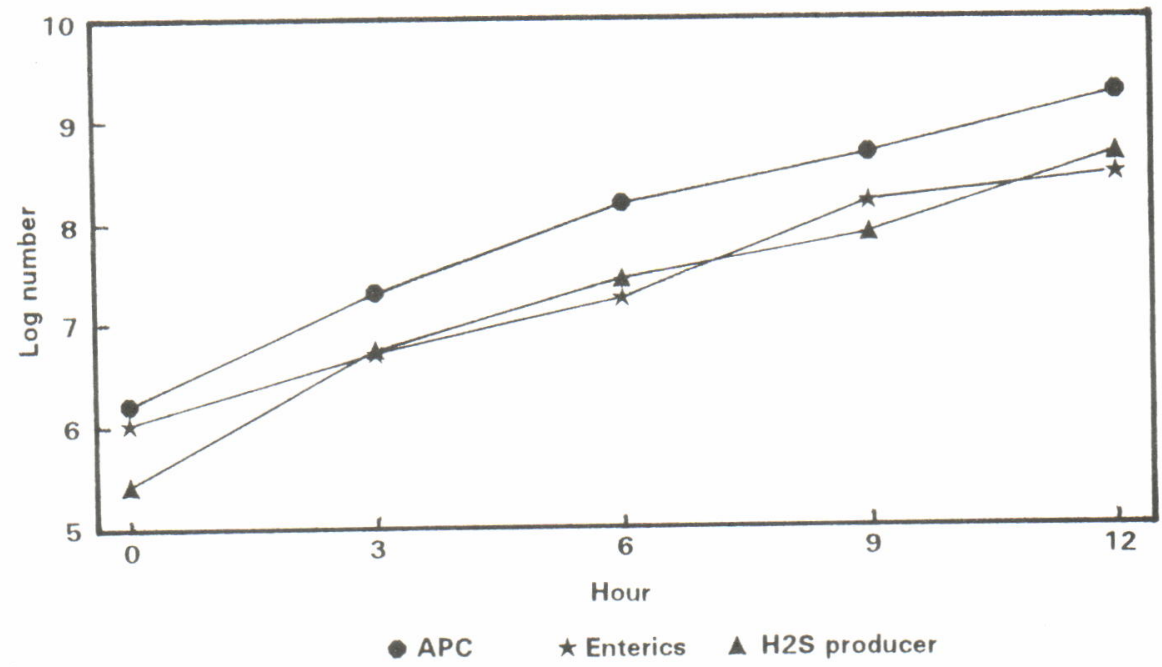

Figure 1. Bacterial changes of fringescale sardine during storage at ambient temperature.

Sebaliknya selama penyimpanan dalam es, ketiga indikator pembusukan tersebut justru mengalami penurunan jumlah, khususnya pada 3 hari pertama untuk jumlah bakteri total dan 5 hari pertama untuk bakteri enterik dan penghasil $\mathrm{H}_{2} \mathrm{~S}$, yang sangat boleh jadi disebabkan oleh matinya bakteri mesofilik dan termofilik. Setelah periode tersebut, perkembangan bakteri tampak terus meningkat (Figure 2).

Dari hasil identifikasi bakteri (Table 2) terlihat bahwa pada penyimpanan suhu kamar, bakteri yang mendominasi pada awal percobaan adalah Enterobacteriaceae $(23 \%)$ dan Aeromonas (22\%), sedangkan pada akhir penyimpanan sebagian besar $(58 \%)$ adalah Enterobacteriaceae di mana bakteri enterik dan penghasil $\mathrm{H}_{2} \mathrm{~S}$ termasuk dalam kelompok tersebut. Dengan penyimpanan dalam es, komposisi mikroflora yang semula didominasi oleh Enterobacteriaceae (39\%), 


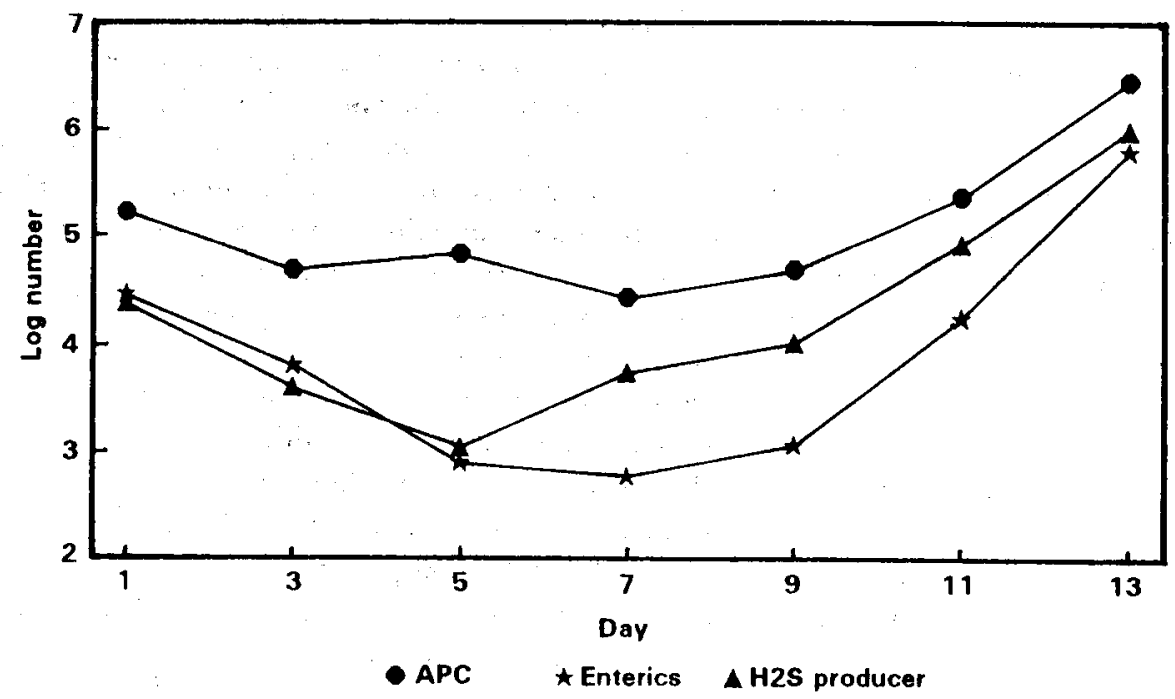

Figure 2. Bacterial changes of fringescale sardine during ice storage

Table 2. Composition (\%) of microfloras grew in fringescale sardine at the initial and end of storage at ambient temperature and in ice.

\begin{tabular}{|c|c|c|c|c|}
\hline \multirow[t]{2}{*}{ Microflora } & \multicolumn{2}{|c|}{$\begin{array}{c}\text { Ambient temperature } \\
\text { storage }\end{array}$} & \multicolumn{2}{|c|}{ Iced storage } \\
\hline & Howr-O & Howr-12 & $D a y-0$ & Day-13 \\
\hline Aeromonas & 22 & 17 & - & $\cdot$ \\
\hline Enterobacteriaceae & 23 & 58 & 39 & - \\
\hline Lactobacillus & 3 & - & 5 & 5 \\
\hline Stapbylococcus & 6 & 2 & - & - \\
\hline Micrococcus & 10 & 3 & $\cdot$ & - \\
\hline Bacillus & 7 & - & - & - \\
\hline Vibrio & 3 & - & 5 & $\cdot$ \\
\hline Pseudomonas & 8 & 7 & 6 & - \\
\hline $\begin{array}{l}\text { Moraxella and } \\
\text { Acinetobacter }\end{array}$ & 14 & 13 & 21 & 70 \\
\hline Flavobacterium & 2 & - & 6 & 30 \\
\hline Corynebacter & 2 & - & 18 & - \\
\hline
\end{tabular}


kelompok Moraxella dan Acinetobacter (21\%) dan Corynebacter (18\%), digantikan oleh kelompok Moraxella dan Acinetobacter (70\%) dan Flavobacterium (30\%). Ketiganya adalah bakteri yang tidak menghasilkan $\mathrm{H}_{2} \mathrm{~S}$, indol maupun acetoin, kecuali beberapa spesies dari Flavobacterium yang menghasilkan indol (Buchanan and Gibbons, 1975). Keadaan tersebut menjelaskan fenomena bahwa ikan yang dies tidak berbau sebusuk ikan yang disimpan pada suhu kamar, walaupun sudah pada tahap akhir penyimpanan. Pola pembusukan ikan tembang ini tampaknya serupa dengan hasil penelitian Anggawaty et al. (1990) menggunakan ikan kerapu lumpur, serta Surendran dan Gopakumar (1981) dengan udang Metapeneaus dobsoni. Surendran dan Gopakumar (1981) menemukan bahwa pada penyimpanan udang dalam es, mikroflora didominasi oleh kelompok Acinetobacter-Moraxella, sedangkan Pseudomonas kurang dari $20 \%$ saat udang membusuk. Adapun untuk ikan kerapu, Anggawaty et al. (1990) menemukan Pseudomonas $80 \%$ dan kelompok Moraxella-Acinetobacter $20 \%$ pada ikan yang dies, sedangkan untuk yang disimpan pada suhu kamar, pembusukan didominasi oleh Enterobacteriaceae $(40 \%)$, Aeromonas (22\%), dan Corynebacter (17\%).

\section{Pengamatan Organoleptil}

Table 3, 4, 5, and Table 6 berikut menunjukkan perubahan mutu organoleptik ikan tembang secara gradual pada kedua macam perlakuan. Pada penyimpanan suhu kamar, ikan ditolak oleh panelis setelah 12 jam penyimpanan suhu kamar, yang pada ikan mentah ditandai oleh timbulnya bau amis dan bau amoniak yang sangat kuat, sedangkan pada ikan masak ditandai oleh adanya rasa asam dan sedikit pahit. Tampak kecenderungan adanya bakteri tertentu yang berpengaruh terhadap bau ikan. Pada waktu ikan dinyatakan busuk, di mana bakteri yang dominan adalah Enterobacteriaceae dan Aeromonas (Table 2), tercium bau amoniak dan bau amis yang sangat kuat, serta sedikit bau belerang. Gillespie dan Macrae (1975) menemukan bahwa 80\% dari bakteri Vibrio dan Aeromonas dapat menghasilkan bau belerang pada suhu $20^{\circ} \mathrm{C}$ dan $60 \%$ dari organisme ini tidak menghasilkan bau pada suhu $5^{\circ} \mathrm{C}$, sedangkan $75 \%$ bakteri Enterobacteriaceae menghasilkan bau amis pada suhu $20^{\circ} \mathrm{C}$ dan hampir tidak menghasilkan bau pada suhu $5^{\circ} \mathrm{C}$.

Adapun pada penyimpanan dalam es, nilai mentah dan nilai masak ikan tembang mengalami penurunan mutu hampir bersamaan dan ikan dinyatakan busuk pada hari ke 13. Menurut Mc.Meekin dan Olley (1985), pertumbuhan mikroorganisme bertanggungjawab pada hampir semua pembusukan daging atau ikan yang disimpan pada suhu rendah, dan pembusukan ini dimulai pada saat jumlah bakteri telah melebihi $10^{7} \mathrm{koloni} / \mathrm{gram}$. Pada penelitian ini, ikan tembang sudah dinyatakan busuk meskipun jumlah bakteri total baru mencapai $2,8 \times 10^{6} \mathrm{koloni} / \mathrm{g}$. Hal ini mungkin disebabkan oleh ukuran ikan tembang yang relatif kecil sehingga membusuk lebih cepat. 
Table 3. Organoleptic changes of raw fringescale sardine during storage at ambient temperature

\begin{tabular}{|c|c|c|c|c|c|}
\hline Decoription & Howoro & Hown-3 & Howr-6 & Homs & 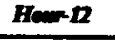 \\
\hline Appearance & very bright & bright & \multicolumn{2}{|c|}{ slightly dull } & dull \\
\hline Skin & \multicolumn{2}{|l|}{ firm } & \multicolumn{3}{|c|}{$\operatorname{soft}$} \\
\hline Scales & firm & \multicolumn{2}{|c|}{ slightly loose } & \multicolumn{2}{|c|}{ loose } \\
\hline slime & absent & \multicolumn{2}{|c|}{ thin, transparent normal smell } & $\begin{array}{l}\text { thick, fisby } \\
\text { smell }\end{array}$ & $\begin{array}{l}\text { thick, } \\
\text { stale smell }\end{array}$ \\
\hline Stiffness & \multicolumn{2}{|c|}{ rigor } & \multicolumn{3}{|c|}{ post-rigor } \\
\hline Eyes & \multicolumn{2}{|c|}{$\begin{array}{l}\text { clear,convex, bright green iris,no blood } \\
\text { stain }\end{array}$} & $\begin{array}{l}\text { slightly } \\
\text { cloudy, } \\
\text { slightly } \\
\text { sunken, } \\
\text { blurred inis, } \\
\text { slightly } \\
\text { bloody }\end{array}$ & \multicolumn{2}{|c|}{$\begin{array}{l}\text { clondy, sligblly swaken, inis } \\
\text { not visible, bloody }\end{array}$} \\
\hline Gills & \multicolumn{3}{|c|}{ pinkish red,thin mucus, fishy smell } & $\begin{array}{l}\text { dark red, } \\
\text { moderate } \\
\text { mucus, } \\
\text { stale smell }\end{array}$ & $\begin{array}{l}\text { dark ned, } \\
\text { excessive } \\
\text { mucus } \\
\text { strong } \\
\text { smell }\end{array}$ \\
\hline Belly & white greyish, firm & \multicolumn{2}{|c|}{ yellowish, sligbtly soft } & \multicolumn{2}{|c|}{ dull brown, sofi } \\
\hline Vent & nomal, fresh smell & $\begin{array}{l}\text { normal, } \\
\text { neutral smell }\end{array}$ & $\begin{array}{l}\text { normal, fisby } \\
\text { smell }\end{array}$ & $\begin{array}{l}\text { sligbt } \\
\text { exudes, } \\
\text { fisby smell }\end{array}$ & $\begin{array}{l}\text { sligbe } \\
\text { exades, } \\
\text { stale smell }\end{array}$ \\
\hline Belly cavity & $\begin{array}{l}\text { opalescent stain, red } \\
\text { blood, fim flesh, } \\
\text { intact viscera }\end{array}$ & \multicolumn{2}{|c|}{$\begin{array}{l}\text { dull opalescent, slightly soft } \\
\text { flesh, intact viscera }\end{array}$} & \multicolumn{2}{|c|}{$\begin{array}{l}\text { greyish brown, red brown } \\
\text { blood, soft flesh, loose } \\
\text { viscera }\end{array}$} \\
\hline $\begin{array}{l}\text { Total demerit } \\
\text { scores }\end{array}$ & 8.00 & 11.50 & 22.00 & 24.00 & 35.50 \\
\hline
\end{tabular}

Table 4. Organoleptic changes of cooked fringescale sardine during storage at ambient temperature

\begin{tabular}{c|c|c|c|c|c}
\hline Description & Howr-0 & Howr-3 & Hour-6 & Hown-9 & How-12 \\
\hline Odour & $\begin{array}{c}\text { very fresh } \\
\text { seaweedy }\end{array}$ & fresh seaweedy & slightly fishy & slightly stale & stale smell \\
\hline Flavour & sweet & $\begin{array}{c}\text { slightly loss of } \\
\text { sweetness }\end{array}$ & almost neutral & neutral & neutral, bland \\
\hline $\begin{array}{c}\text { Texture } \\
\text { ability }\end{array}$ & \multicolumn{2}{|c|}{ very firm, juicy } & slightly soft & soft & very soft \\
\hline Mean scores & 4.62 & good & $\begin{array}{c}\text { neitber good } \\
\text { nor bad }\end{array}$ & slightly poor & poor \\
\hline
\end{tabular}


Indriati, N. dan Heruwati, E.S.

Table 5. Organoleptic changes of raw fringescale sardine during storage in ice

\begin{tabular}{|c|c|c|c|c|c|c|c|}
\hline Description & $\operatorname{dog} 0$ & $\operatorname{dog} 3$ & $d a y 5$ & $\operatorname{dog} 7$ & $d a y-9$ & $d x-11$ & $d g-13$ \\
\hline Appearance & very bright & \multicolumn{2}{|c|}{ bright } & \multicolumn{2}{|c|}{ slightly dull } & \multicolumn{2}{|c|}{ dull } \\
\hline Skin & \multicolumn{2}{|c|}{ firm } & \multicolumn{2}{|c|}{ slightly soft } & \multicolumn{3}{|c|}{ soft,finger identation remain } \\
\hline Scales & firm & \multicolumn{4}{|c|}{ slightly loose } & \multicolumn{2}{|c|}{ loose } \\
\hline Slime & $a b s e n t$ & \multicolumn{5}{|c|}{ thin, transparent, normal smell } & $\begin{array}{l}\text { thick } \\
\text { fishy } \\
\text { smell }\end{array}$ \\
\hline Stiffness & \multicolumn{2}{|c|}{\begin{tabular}{|c|} 
rigor \\
\end{tabular}} & \multicolumn{5}{|c|}{ post rigor } \\
\hline Eyes & \multicolumn{2}{|c|}{$\begin{array}{c}\text { clear,convex, bright } \\
\text { green iris, no blood stain }\end{array}$} & \multicolumn{3}{|c|}{$\begin{array}{l}\text { slightly cloudy, slightly sunken, } \\
\text { blurred iris, slightly bloody }\end{array}$} & \multicolumn{2}{|c|}{$\begin{array}{l}\text { cloudy,sunken dull, } \\
\text { iris not visible, } \\
\text { sligbtly bloody }\end{array}$} \\
\hline Gills & $\begin{array}{l}\text { brigt pink, } \\
\text { mucus } \\
\text { absent } \\
\text { fresb } \\
\text { seaweedy } \\
\text { smell }\end{array}$ & \multicolumn{2}{|c|}{$\begin{array}{l}\text { pinkish red, thin } \\
\text { mucus, slightly fisby }\end{array}$} & \multicolumn{3}{|c|}{$\begin{array}{l}\text { slightly faded pink, moderate } \\
\text { mucus, fishy smell }\end{array}$} & $\begin{array}{c}\text { dull } \\
\text { pink, } \\
\text { exessive } \\
\text { mucus } \\
\text { strong } \\
\text { fisby } \\
\text { stale } \\
\text { smell }\end{array}$ \\
\hline Belly & \multicolumn{3}{|c|}{ White greyish, firm } & \multicolumn{2}{|c|}{$\begin{array}{l}\text { dull yellowish, } \\
\text { slightly soft }\end{array}$} & \multicolumn{2}{|c|}{ dull brown, soft } \\
\hline Vent & \multicolumn{4}{|c|}{ normal condition, fresh smell } & $\begin{array}{c}\text { normal } \\
\text { condition, } \\
\text { neutral } \\
\text { smell }\end{array}$ & \multicolumn{2}{|c|}{$\begin{array}{c}\text { slight exudes, fishy } \\
\text { stale smell }\end{array}$} \\
\hline Belly cavity & \multicolumn{2}{|c|}{$\begin{array}{l}\text { opalescent stain,dark } \\
\text { red blood, firm flesh, } \\
\text { intact viscera }\end{array}$} & \multicolumn{3}{|c|}{$\begin{array}{c}\text { dull opalescent, dark red } \\
\text { blood,slightly soft flesh, intact } \\
\text { viscera }\end{array}$} & \multicolumn{2}{|c|}{$\begin{array}{l}\text { greyisb yellow } \\
\text { brown,red brownish } \\
\text { blood, soft flesh, } \\
\text { loose viscera }\end{array}$} \\
\hline $\begin{array}{l}\text { Total demerit } \\
\text { scores }\end{array}$ & 5.00 & 8.00 & 11.50 & 15.00 & 18.50 & 26.50 & 33.50 \\
\hline
\end{tabular}

\section{Pengamatan Kimiawi}

Pada penyimpanan suhu kamar, indikator pembusukan, yaitu total basa menguap (TVB), trimetilamin (TMA), dan amonia $\left(\mathrm{NH}_{3}\right.$ ) rata-rata meningkat kadarnya, walaupun dengan laju yang berbeda (Figure 3). Pada penyimpanan dalam es, terlihat ketiga indikator pembusukan tersebut juga meningkat selama penyimpanan, namun dengan laju yang jauh lebih rendah dibandingkan dengan penyimpanan pada suhu kamar (Figure 4). Dengan penyimpanan dalam es, peningkatan TVB sebesar $31 \%$ (dari 17,57 menjadi $22,95 \mathrm{mg} \%$ ), TMA $262 \%$ (dari 1,95 menjadi 7,06 mg\%), dan amonia 229\% (dari 1,4 menjadi 4,6 ppt) baru 
Table 6. Organoleptic changes of cooked ice-stored fringescale sardine

\begin{tabular}{c|c|c|c|c|c|c|c}
\hline Description & daty-0 & day-3 & day-5 & day-7 & day-9 & day-11 & day-13 \\
\hline Odour & $\begin{array}{c}\text { very fresh, } \\
\text { seaweedy }\end{array}$ & $\begin{array}{c}\text { fresh } \\
\text { seaweedy }\end{array}$ & \multicolumn{2}{|c|}{ slightly neutral } & $\begin{array}{c}\text { slightly } \\
\text { stale }\end{array}$ & $\begin{array}{c}\text { stale, } \\
\text { strong } \\
\text { fishy }\end{array}$ \\
\hline Flavour & sweet & \multicolumn{2}{|c|}{$\begin{array}{c}\text { slightly loss of } \\
\text { sweetness }\end{array}$} & $\begin{array}{c}\text { neutral } \\
\text { bland }\end{array}$ & $\begin{array}{c}\text { slightly } \\
\text { sour and } \\
\text { bitter }\end{array}$ & $\begin{array}{c}\text { sour and } \\
\text { bitter }\end{array}$ \\
\hline Texture & firm, juicy & $\begin{array}{c}\text { firm, slightly loss of } \\
\text { juice }\end{array}$ & $\begin{array}{c}\text { slightly } \\
\text { loss of } \\
\text { firmness }\end{array}$ & \multicolumn{2}{|c|}{ slightly soft } \\
\hline $\begin{array}{c}\text { General } \\
\text { acceptability }\end{array}$ & very good & \multicolumn{2}{|c|}{ good } & \multicolumn{2}{|c|}{ fair } & poor \\
\hline $\begin{array}{c}\text { Mean } \\
\text { scores }\end{array}$ & 5.00 & 4.15 & 3.75 & 3.50 & 3.37 & 2.87 & 2.10 \\
\hline
\end{tabular}

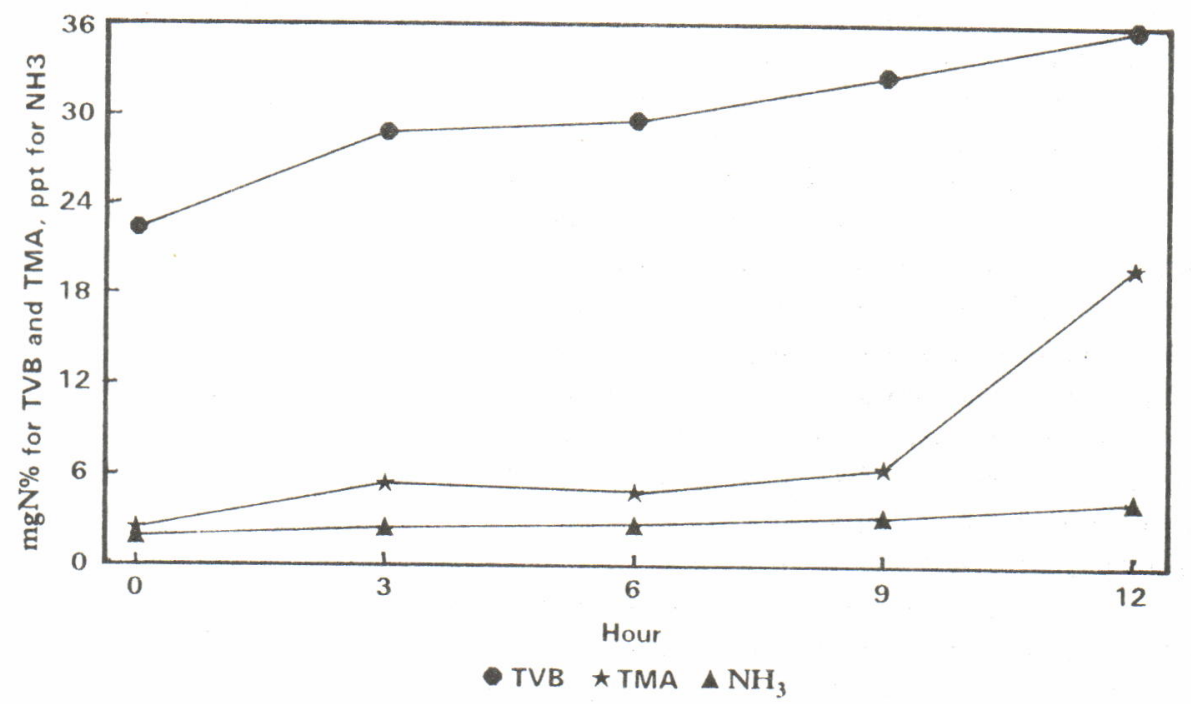

Figure 3. Chemical changes of fringescale sardine during storage at ambient temperature

tercapai setelah 13 hari, sedangkan pada suhu kamar, peningkatan TVB sebesar $60 \%$ (dari 22,28 menjadi $35,72 \mathrm{mg} \%$ ), TMA $713 \%$ (dari 2,44 menjadi 19,83 $\mathrm{mg} \%$ ), dan amonia $132 \%$ (dari 1,9 menjadi 4,4 ppt) sudah tercapai dalam waktu hanya 12 jam. 


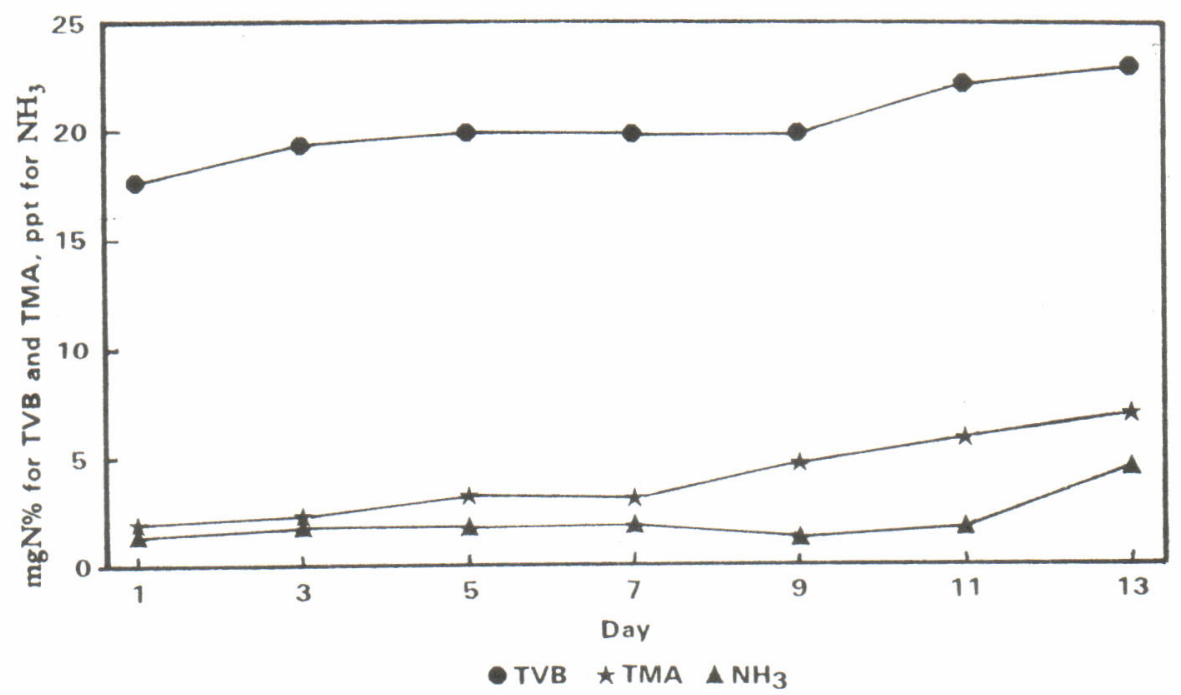

Figure 4. Chemical changes of fringescale sardine during ice storage

Selain laju peningkatan indikator pembusukan yang rendah, selama penyimpanan dalam es, nilai indikator yang tercapai pun rendah. Pada saat ditolak oleh panelis, ikan yang disimpan dalam es mencapai nilai TVB, TMA, dan amoniak berturut-turut $22,95 \mathrm{mgN} \%, 7,06 \mathrm{mgN} \%$, dan 4,6 ppt, sedangkan yang disimpan pada suhu kamar telah mencapai nilai TVB 35,72 mgN\%, TMA $19,83 \mathrm{mgN} \%$, dan amoniak 4,4 ppt. Rendahnya nilai indikator tersebut selain disebabkan oleh rendahnya laju pembusukan akibat menurunnya aktivitas bakteri pembusuk dan aktivitas enzim pembusukan pada suhu rendah, juga oleh efek penirisan (leaching effect) seperti yang ditemui oleh Basu dan Khasim (1985). Pergantian komposisi bakteri yang hidup pada suhu rendah diduga juga berpengaruh terhadap laju pembentukan TMA, karena kemungkinan sebagian bakteri pembentuk TMAO, yang merupakan prekursor TMA, mati karena suhu rendah. Sebaliknya pada suhu kamar, kadar TMA pada akhir percobaan sangat tinggi. Bila dikaitkan dengan hasil pengamatan mikrobiologi, di mana bakteri yang bertanggungjawab dalam pembusukan ikan yang disimpan pada suhu kamar adalah Enterobacteriaceae (58\%) dan Aeromonas (17\%), hasil ini menjadi sangat gayut (relevant) karena kedua jenis bakteri di atas memang bersifat dapat mereduksi TMAO menjadi TMA.

\section{KESIMPUL.AN DAN SARAN}

Dari pengamatan organoleptik baik terhadap ikan mentah maupun ikan masak, ternyata ikan tembang yang disimpan dalam es dapat tahan selama 13 hari, sedangkan bila dibiarkan pada suhu kamar hanya tahan selama 12 jam saja. 
Flora bakteri yang mendominasi ikan tembang saat masih baru ditangkap adalah Aeromonas, Enterobacteraiceae, Corynebacter, dan kelompok MoraxellaAcinetobacter. Pada saat membusuk, ikan yang disimpan dalam es didominasi oleh kelompok Moraxella-Acinetobacter dan Flavobacterium, sedangkan ikan yang disimpan pada suhu kamar oleh Enterobacteriaceae dan Aeromonas.

Perbedaan jenis bakteri penyebab pembusukan ini ternyata juga mempengaruhi pola pembusukan yang terdeteksi dari pengamatan organoleptik. Saat ditolak oleh panelis, ikan yang disimpan dalam es tidak berbau sebusuk ikan yang disimpan pada suhu kamar karena Moraxella, Acinetobacter, dan Flavobacterium tidak memproduksi senyawa-seny awa berbau busuk seperti $\mathrm{H}_{2} \mathrm{~S}$, indol, dan acetoin yang biasa dihasilkan oleh Enterobacteriaceae dan Aeromonas.

TVB, TMA, dan amonia, yang dianggap sebagai indikator pembusukan ikan, baik pada penyimpanan dalam es maupun suhu kamar menunjukkan peningkatan selama penyimpanan walaupun dengan laju dan nilai yang berbeda untuk kedua perlakuan.

Dari hasil yang diperoleh di atas dapat disimpulkan bahwa ikan tembang memerlukan penyimpanan pada suhu rendah secepat mungkin setelah ditangkap, agar mutu kesegarannya dapat dipertahankan. Secara organoleptis, mikrobiologis, dan kimiawi terbukti bahwa pada suhu kamar, ikan memasuki ambang batas pembusukan setelah 6 jam, atau dengan kata lain, bila trip penangkapan melebihi 6 jam, maka perahu/kapal penangkap ikan tembang harus dilengkapi dengan es bila menginginkan hasil tangkapan yang masih bagus mutunya saat diterima konsumen.

\section{DAFTAR PUSTAKA}

Anggawati A.M., N.Indriati, dan E.S.Heruwati. 1990. Mesophilic and psychrotropic spoilage of grouper. Asean Food. J. 5 (1): 17-26

Basu, S. and D.I. Khasim. 1985. Studies on the effect of leaching on the quality of ice stored fish. Fish Technol. 22(2): 105-108.

Branch, A.C. and A.M.A. Vail. 1985. Bringing fish into the computer age. Food Technol. Austr. 37(8): 352-355.

Bremner, H.A.; J. Olley; J.A. Statham and A.M.A. Vail. 1988. Nucleotide catabolism: Influence on the storage life of tropical fish from North West Shelf of Australia. J.Food Sci. 53(1): 6-11.

Buchanan R.E. and N.E. Gibbons (co-ed). 1975. Bergey's manual of determinative bacteriology. The William \& Wilkins Co.; Baltimore, 1268p.

Bustaman, S.; A.C. Chumaidi and F. Syarif. 1982. Spoilage of mackerel during storage. Res.Rep.Fish.Tech. RIFT. 19: 1-6. 
Indriati, N. dan Heruwati, E.S.

Gillespie, N.C. and I.C. Macrae. 1975. The bacterial flora of some Queensland fish and its ability to cause spoilage. J. Appl. Bact. 39: 91-100.

Mc. Meekin, T.A. and J. Olley. 1985. Predictive microbiology. Food Technol. Austr. 38: 331-334.

Putro, S.; M.Saleh and B.S.B. Utomo. 1984. Storage life of rabbit fish (Siganus sp.) during icing. Res. Rep. Fish. Tech. RIFT. 35: 25-34.

Saleh, M.; Purwadi,S. Putro and E. Gorczyca. 1984a. Storage life of mullet (Mugil sp.). Res. Rep. Fish. Tech. RIFT. 37: 27-32.

Saleh, M.; Purwadi, and S. Putro. 1984b. Storage life of iced skipjack (Katsuwonus pelamis). Res. Rep. Fish. Technol. 34: 23-26.

Shewan, J.M. 1977. The bacteriology of fresh spoiling fish and the biochemical changes induced by bacterial action. In: Proceeding of the Conference on Handling, Processing, and Marketing of Tropical Fish. Tropical Product Institute, London: 56-66.

Surendran, P.K. and K. Gopakumar. 1981. Selection of bacterial flora in the chlortetracycline treated oil sardine (Sardinella longiceps), Indian mackerel (Rastrelliger kanagurta) and prawn (Metapenaeus dobsoni) during ice storage. Fish Technol. No.8: 133-141.

Tambunan, P.R. and Saifurijal. 1972. Icing of red snapper, yellowfin tuna, small tuna, and skipjack, Res. Rep. Fish. Technol. RIFT. No.2.

Wheaton, F.W. and Lawson, T.B. 1985. Proc. Aq. Food Prod., A. Willey Interscience Publication. John Wiley \& Sons, N.Y. 518 p. 